\title{
Do the Integrated Health Posts Have Contextual Effect on Birth Weight? A Multilevel Evidence from Situbondo, East Java
}

\author{
Eti Kuswandari'), Harsono Salimo²), Yulia Lanti Retno Dewi3) \\ 1)Masters Program in Public Health, Universitas Sebelas Maret \\ 2)Department of Pediatrics, Dr. Moewardi Hospital \\ 3)Faculty of Medicine, Universitas Sebelas Maret
}

\section{ABSTRACT}

Background: Low birth weight babies (LBW) are sensitive indicators of socioeconomic conditions and indirectly become a benchmark for maternal and child health. This study aimed to analyze contextual effect of integrated health post and socioeconomic determinants on LBW in Situbondo.

Subjects and Method: This was an observational analytic study with a case control design. The study was conducted at the integrated health posts in the Asembagus Health Center. The study population was all infants aged 0-1 years. A sample of 150 infants with normal birthweight and 50 LBW was selected by simple random sampling. The dependent variable was LBW. The independents variables were maternal age, maternal education, maternal occupation, maternal knowledge, family income, exposure to cigarette smoke, and integrated health post strata. Data were analyzed using multilevel multiple logistic regression analysis using STATA 13.

Results: The risk of LBW increased with maternal age $<20$ years or $\geq 35$ years $(b=1.78 ; 95 \% \mathrm{CI}=$ 0.83 to $2.73 ; \mathrm{p}<0.001)$, low maternal education $(b=0.93 ; 95 \%$ CI $<0.01$ to $1.86 ; p=0.049)$, mother working outside the home $(b=1.24 ; 95 \%$ $\mathrm{CI}=0.26$ to $2.22 ; \mathrm{p}=0.013$ ), low family income $(b=1.33 ; 95 \% \mathrm{CI}=0.42$ to $2.24 ; \mathrm{p}=0.004)$, low maternal knowledge $(b=1.17 ; 95 \% \mathrm{CI}=0.13$ to $2.21 ; p=0.026)$, and high cigarette smoke exposure $(b=1.11 ; 95 \% C I=0.08$ to $2.13 ; p=0.035)$. Integrated health post has not contextual effect on $\mathrm{LBW}$ with $\mathrm{ICC}=0.01 \%$.

Conclusion: The risk of LBW increases with maternal age $<20$ years or $\geq 35$ years, low maternal education, low maternal education, mother working outside the home, low family income, low maternal knowledge, and high cigarette smoke exposure. Integrated health post has not contextual effect on LBW.

Keywords: low birthweight, socio-economic determinants, integrated health post

\section{Correspondence:}

Eti Kuswandari. Masters Program in Public Health, Universitas Sebelas Maret. Jl. Ir. Sutami 36A, Surakarta 57126, Central Java. Email: etikuswandari.ek@gmail.com. Mobile : +6282132770153 .

\section{Cite this as:}

Kuswandari E, Salimo H, Dewi YLR (2020). Do the Integrated Health Posts Have Contextual Effect on Birth Weight? A Multilevel Evidence From Situbondo, East Java. J Matern Child Health. 05(03): 275-286. https://doi.org/10.26911/thejmch.2020.05.03.06.

(i) (2) Journal of Maternal and Child Health is licensed under a Creative Commons

\section{BACKGROUND}

World Health Organization (WHO) in 2017 defines low birth weight (LBW) is the weight of the baby at birth is less than 2500 grams. Low birth weight is one of the problems that continues to occur globally and causes the long-term and short-term risks posed (WHO,
2014).

Low birth weight babies (LBW) are sensitive indicators of socioeconomic conditions and indirectly become a benchmark of maternal and child health (Joshi et al., 2011).

WHO recorded 4.2 million or $75 \%$ of all under-five deaths occurred in the first year of 
life, recorded 30.5 deaths per 1000 live births in 2016 (WHO, 2017). According to WHO in 2015 in the world the occurrence of LBW is $15.5 \%$ which means that around 20.6 million babies are born every year (WHO, 2014).

The high incidence of babies born with low body weight has a significant contribution in neonatal and infant mortality rates, because babies with low birth weight (LBW) have a high risk of early growth retardation of infectious diseases, developmental delays and death during the period infancy and childhood (WHO, 2017).

Low Birth Weight (LBW) is one of the second leading causes of death in Indonesia after Intra Uterine Fetal Death (IUFD) which is as much as $11.2 \%$ (Ministry of Health, 2019). According to Pantiwati, (2010) the mortality rate that occurs in low birth weight (LBW) is 35 times higher compared to babies with normal birth weight.

Based on Basic Health Research data (2018), it shows that the percentage of low birth weight in Indonesia is $6.2 \%$. East Java Province is one of the highest contributors to LBW, which is $6.9 \%$. According to data from the East Java Health Office (2018), obtained from 4,753 where live birth rates. Situbondo Regency is the number one contributor to the LBW incidence rate of 695 or $7.7 \%$ of 4,753 live births.

According to Yuwono's (2015), it shows that socio-economic variables affecting the incidence of infants with LBW are maternal family income, maternal education level and maternal family status do not influence LBW incidents. Variable characteristics of pregnant women that affect the incidence of LBW infants are maternal length of pregnancy and maternal weight gain while maternal age parity and distance of delivery do not affect LBW incidence. Variables in the behavior of pregnant women that affect the incidence of infants with LBW are exercise, resting hours, frequency adjacent to smokers. Lots of $\mathrm{Fe}$ (iron) consumed and nutritional conditions do not affect LBW events. The most influential factor on the incidence of babies with LBW is the maternal family income and the length of the mother's pregnancy.

Problems that occur in babies with low birth weight (LBW), especially those premature, occur because of inattention of the organ systems in these babies. Problems with LBW that often occur are disorders of the respiratory system, central nervous system, cardiovascular, hematological, gastrointestinal, kidney, thermo-regulation (Maryunani, 2009).

LBW can be prevented by increasing periodic pregnancy checks at least 4 times during the pregnancy period and starting at a young gestational age, health education about the growth and development of the fetus in the womb, danger signs during pregnancy and self-care during pregnancy so that they can maintain their health and the fetus in the womb properly, mothers should be able to plan their deliveries in the period of healthy reproduction (20 years - 34 years). Support from other related sectors to play a role in improving maternal education and family economic status so that they can increase access to the use of antenatal services and the nutritional status of mothers during pregnancy (Proverawati, 2010).

Health service performance is one of the important factors in efforts to improve the quality of population health. To monitor the health and growth of children under five, the community can use integrated health post. At present there are an estimated 240,000 integrated health posts throughout Indonesia, both urban and rural. Efforts to reduce the health problems of infants and toddlers can be sought by utilizing access to health services such as Integrated Health Posts, which is managed by the community themselves. Integrated health posts activities include immunization, weighing, supplemen- 
tary feeding and nutrition and health counseling (Hidayat and Jahari, 2011).

The results of a preliminary study showed that the number of LBW cases in 2017 was 695 cases (7.72\%). In 2018 the number of LBW cases were 706 cases $(7.7 \%)$ and resulted in 53 cases (43.8\%) cases of infant mortality. Low birth weight is one of the causes of infant mortality in Situbondo District (Situbondo Health Office, 2019).

Based on the above problems, the authors are interested in conducting research with the title "Integrated health posts contextual influence and socioeconomic determinants of the incidence of low birth weight (LBW) in Situbondo Regency”.

\section{SUBJECTS AND METHOD}

\section{Study Design}

This was a case control study conducted at integrated health posts in Asembagus Health Center, East Java, Indonesia, from January to February 2020.

\section{Population and Sample}

The source population was infants who live in the work area of the Asembagus Health Center. A sample of 200 infants consisted of 50 low birthweight babies and 150 normal birthweight was selected randomly.

\section{Study Variables}

The dependent variable was LBW. The independent variables were maternal age, maternal education, maternal occupation, family income, maternal knowledge, exposure to cigarette smoke, health personnel support, and, and integrated health posts strata.

\section{Operational Definition of Variables}

Birth weight was the baby's weight at birth measured in grams. The measurement scale was continous and transformed into dichotomous.

Maternal age was the age of the mother at the time of delivery. The measurement scale was continous and transformed into dichotomous, coded $\mathrm{O}=<20$ years or $\geq 35$ years and $1=20-35$ years.

Maternal education was the status of formal education (elementary, junior high, high school, college) that is taken by mothers based on the last diploma obtained. The measurement scale was categorical, code $\mathrm{o}$ $<$ Senior high school and $1 \geq$ Senior high school.

Maternal occupation was the work of mothers inside or outside the house both formal and informal which is done in the amount of time spent during the day. The measurement scale was categorical, coded $\mathrm{o}=$ work inside the home, $\mathbf{1}=$ work outside the home.

Family income was the amount of family income received in one month as a family economic source. Revenues can be measured by Regency or City Minimum Wages. The measurement scale was continous and transformed into dichotomous, coded $\mathrm{O}=<$ minimum wage ( $\operatorname{Rp~1,763,000),~} 1=\geq$ minimum wage ( $\operatorname{Rp} 1,763,000)$.

Exposure to cigarette smoke was a situation where mothers are often exposed to cigarette smoke caused by members of the house who smoke, work colleagues, and public places. The measurement scale was continous and transformed into dichotomous, coded $\mathrm{o}=$ rarely exposed, $1=$ often exposed.

Maternal knowledge was the mother's knowledge of low birth weight (LBW) in terms of understanding, characteristics, prevention, and care of babies with low birth weight. The measurement scale was continous and transformed into dichotomous, coded $\mathrm{O}=$ low $($ score $<5), 1=\operatorname{good}($ score $\geq 5$ ). Integrated health post was the level of integrated health posts development that has been determined by special criteria and special assessments set by the Indonesian Ministry of Health. The measurement scale was categorical, $1=$ madya, $2=$ purnama, $3=$ mandiri. 
Kuswandari et al./ Do the integrated health posts have contextual effect on LBW

\section{Study Instruments}

The research instrument used for data collection was a questionnaire that had been tested for validity and reliability. The questionnaire was used to measure maternal age, maternal education, maternal occupation, maternal knowledge, exposure to cigarette smoke, family income, health workers support, and strata of integrated health posts.

\section{Data Analysis}

Univariate analysis was performed to see the frequency distribution and percentage characteristics of samples. Bivariate analysis was conducted to study the relationship between independent variables and low birthweight using the chi-square. Multivariate analysis was performed using multiple multilevel logistic regression analysis to determine the integrated health posts contextual influence on the socioeconomic determinants of LBW.

\section{Research Ethics}

Ethical clearance in this study was obtained from the Health Research Ethics Commission of Moewardi Hospital Surakarta City with the number 1.342 / XII / HREC / 2019 published on December 13, 2019.

\section{RESULTS}

\section{Sample Characteristics}

Characteristics in this study include age, gender, education, occupation, and income. These characteristics are shown in Table 1 and 2.

\section{Bivariate analysis}

The analytical test used in the bivariate analysis is the chi square test. Bivariate analysis based on the results of this study can be seen in Table 3.

\section{Table 1. Sample Characteristics (Continuous Data)}

\begin{tabular}{lccccc}
\hline Variable & n & Mean & SD & Min. & Max. \\
\hline Maternal age & 200 & 24.38 & 5.67 & 15 & 45 \\
Family Income (Rupiah) & 200 & $1,948,500$ & $6,520,919$ & 1, ooo,ooo & 5, ooo, 000 \\
Maternal Knowledge & 200 & 3.24 & 1.38 & 1 & 5 \\
Smoke exposure & 200 & 6.6 & 1.60 & 3 & 11 \\
Health personnel support & 200 & 10.60 & 0.58 & 9 & 11 \\
\hline
\end{tabular}

Table 2 Sample Characteristics (Dichotomous Data)

\begin{tabular}{|c|c|c|c|}
\hline Characteristics & & $\mathbf{n}$ & $\%$ \\
\hline \multirow[t]{2}{*}{ Maternal age } & 20-35 years old & 151 & $75 \cdot 5$ \\
\hline & $<20$ years old and $>35$ years old & 49 & 24.5 \\
\hline \multirow[t]{2}{*}{ Maternal education } & Higher education ( $\geq$ SHS) & 151 & $75 \cdot 5$ \\
\hline & Primary School (<SHS) & 49 & 24,5 \\
\hline \multirow[t]{2}{*}{ Mother's occupation } & Working at home & 115 & 57.5 \\
\hline & Working outside of home & 85 & 42.5 \\
\hline \multirow[t]{2}{*}{ Family Income } & High ( $\geq$ minimum wage) & 115 & 57.5 \\
\hline & Rendah (<minimum wage) & 85 & 42.5 \\
\hline \multirow[t]{2}{*}{ Maternal knowledge } & Good & 172 & 86 \\
\hline & Poor & 28 & 14 \\
\hline \multirow[t]{2}{*}{ Smoke exposure } & Low exposure & 76 & 38 \\
\hline & High exposure & 124 & 62 \\
\hline \multirow[t]{2}{*}{ Health personnel support } & Strong & 200 & 100 \\
\hline & Weak & $\mathrm{O}$ & $\mathrm{O}$ \\
\hline
\end{tabular}

\section{Multiple multilevel analysis}

Multiple multilevel logistic regression analysis was carried out to explain the effects of more than one independent variables (mater- nal age, maternal education, maternal occupation, family income, maternal knowledge, exposure to cigarette smoke, health workers support, and integrated health posts strata) 
Kuswandari et al./ Do the integrated health posts have contextual effect on LBW

to the dependent variable (LBW). The results

Table 4 .

of multiple multilevel analysis can be seen in

Table 3 Bivariate analysis of determinants of LBW

\begin{tabular}{|c|c|c|c|c|c|c|}
\hline \multirow{3}{*}{ Independent Variable } & \multicolumn{4}{|c|}{ Birth Weight } & \multirow{3}{*}{$\mathbf{O R}$} & \multirow{3}{*}{$\mathbf{p}$} \\
\hline & \multicolumn{2}{|c|}{ LBW } & \multicolumn{2}{|c|}{ NBW } & & \\
\hline & $\mathbf{n}$ & $\%$ & $\mathbf{n}$ & $\%$ & & \\
\hline \multicolumn{7}{|l|}{ Maternal age } \\
\hline 20-35 years old & 22 & 14.5 & 129 & 85.4 & 7.81 & $<0.001$ \\
\hline \multicolumn{6}{|l|}{ Maternal education } & \\
\hline High ( $\geq$ Senior high school) & 22 & 14.5 & 130 & 85.5 & 7.81 & $<0.001$ \\
\hline Low (<Senior high school) & 28 & 58.4 & 20 & 41.6 & & \\
\hline \multicolumn{7}{|l|}{ Maternal Occupation } \\
\hline Working at home & 28 & 19.7 & 114 & 10.3 & 4.12 & 0.007 \\
\hline Working outside of home & 22 & 38 & 36 & 62 & & \\
\hline \multicolumn{7}{|l|}{ Family Income } \\
\hline high ( $\geq$ minimum wage) & 14 & 12.5 & 98 & 87.5 & 4.12 & $<0.001$ \\
\hline \multicolumn{7}{|l|}{ Maternal Knowledge } \\
\hline Good & 30 & 17.6 & 140 & 82.4 & $9 \cdot 33$ & $<0.001$ \\
\hline Poor & 20 & 66.7 & 10 & $33 \cdot 3$ & & \\
\hline \multicolumn{7}{|l|}{ Smoke exposure } \\
\hline Low & 7 & 9.3 & 69 & 90.7 & 5.23 & $<0.001$ \\
\hline High & 43 & 34.6 & 81 & 65.4 & & \\
\hline
\end{tabular}

Table 4 Multilevel Multiple Logistic Regression Analysis of Low Birth Weight Infants

\begin{tabular}{|c|c|c|c|c|c|}
\hline \multirow[b]{2}{*}{ Independent Variable } & \multirow{2}{*}{$\begin{array}{l}\text { Regression } \\
\text { Coefficient } \\
\text { (b) }\end{array}$} & \multirow[b]{2}{*}{ SE } & \multicolumn{2}{|c|}{ CI 95\% } & \multirow[b]{2}{*}{$\mathrm{p}$} \\
\hline & & & $\begin{array}{l}\text { Lower } \\
\text { Limit }\end{array}$ & $\begin{array}{l}\text { Upper } \\
\text { Limit }\end{array}$ & \\
\hline \multicolumn{6}{|l|}{ Fixed Effect } \\
\hline Maternal age $(<20$ or $>35$ years $)$ & 1.78 & 0.48 & 0.83 & 2.73 & $<0.001$ \\
\hline $\begin{array}{l}\text { Maternal education (high or primary school } \\
(<\text { SHS) }\end{array}$ & 0.93 & 0.47 & 0.00 & 1.86 & 0.049 \\
\hline Maternal occupation Outside of house & 1.24 & 0.50 & 0.26 & 2.22 & 0.013 \\
\hline Family Income Low (<minimum wage) & 1.33 & 0.46 & 0.42 & 2.24 & 0.004 \\
\hline Maternal knowledge (Poor) & 1.17 & 0.52 & 0.13 & 2.21 & 0.026 \\
\hline Exposure of smoke (High exposed) & 1.11 & 0.52 & 0.08 & 2.13 & 0.035 \\
\hline Costanta & 4.13 & 0.60 & $5 \cdot 32$ & 2.94 & $<0.001$ \\
\hline $\begin{array}{l}\text { Random Effect } \\
\text { Var (Costanta) } \\
\text { n observation= } 200 \\
\text { n grup }=25 \\
\text { Log Likelihood }=-71.27 \\
\text { Average of group= } 8 \text { Min }=8 \text { Max }=8 \\
p=<0.001 \\
\mathrm{ICC}=0.01 \%\end{array}$ & 3.61 & & & & \\
\hline
\end{tabular}

Table 4 showed the effect of maternal age on the risk of LBW. Maternal age $<20$ years old or $\geq 35$ years old are (logodd) likely to deliver infants with LBW 1.78 units higher than mothers aged $20-35$ years $(b=1.78 ; 95 \%$ CI 0.83 to 2.73 ; $\mathrm{p}<0.001$ ).

There was an effect of maternal education on the risk of LBW. Mothers with low 
education ( $<$ Senior high school) have the possibility (logodd) to deliver infants with LBW 1.50 units greater than those with higher education $(b=0.93$; 95\% CI 0.00 to 1.86; $\mathrm{p}=0.049$ ).

There was an effect of maternal occupation on the risk of LBW. Mothers who have work outside the home have the possibility (logodd) for delivery infants with LBW 1.24 units higher than mothers who work at home $(b=1.24 ; 95 \% \mathrm{CI}=0.26$ to $2.22 ; \mathrm{p}=0.013)$.

There was an effect of family income on the risk of LBW. Low family income increased (logodd) the likelihood of LBW 1.33 units higher than high family income $(b=$ 1.33; 95\% CI 0.42 to $2.24 ; \mathrm{p}=0.004$ ).

There was an effect of maternal knowledge on the risk of LBW. Mothers with low knowledge had the possibility (logodd) to deliver LBW infants 1.17 units higher than those with good knowledge $(\mathrm{b}=1.17 ; 95 \% \mathrm{CI}=$ 0.13 to $2.21 ; \mathrm{p}=0.026$ ).

There was an effect of high exposure to cigarette smoke on the risk of LBW. Mothers who are exposed to high cigarette smoke have logodd to deliver LBW infants 1.11 higher than those with low exposure to cigarette smoke $(b=1.11 ; 95 \% \mathrm{CI}=0.08$ to $2.13 ; \mathrm{p}=$ o.035).

There was no contextual effect of integrated health posts on the incidence of low birth weight $(\mathrm{ICC}=0.01 \%)$. That was because the support of health workers provides good support in every integrated health posts available.

\section{DISCUSSION}

\section{The effect of maternal age on the} incidence of low birth weight

The results of this study indicate that maternal age over 35 years tends to be more at risk of experiencing health problems and complications in pregnancy, thereby increasing the risk of premature birth. Advanced maternal age is also associated with a decrease in fetal growth potential caused by aging of maternal biological tissue and the cumulative effect of the disease which can cause low birth weight (Fukuda et al., 2017).

Other study also mentions if mothers aged $<20$ years and $>35$ years have the risk of giving birth to babies with low birth weight compared to mothers who have the age of 2030 years. Mothers who are $<20$ years old tend to have physical and emotional immature and lack of knowledge to care for themselves during pregnancy so that LBW can occur (Ngwira and Stanley, 2015).

Paramitasari et al. (2018) stated that there is a direct influence between maternal age during pregnancy and the incidence of low birth weight. Mothers who are $<20$ years old or $>35$ years old increase the risk of babies born with low birth weight. The same results was reported by Agorinya et al. (2018), which showed that maternal age was a determinant factor for low birth weight.

Maternal age $<20$ years and $\geq 35$ years increases the incidence of low birth weight, so the government makes efforts to prevent this by preventing sexual education for adolescents to reduce the incidence of pregnancy outside of marriage and reduce the number of marriages impact on pregnancy at the age of $<20$ years. In addition, the government should also increase socialization on family planning programs in order to reduce the incidence of pregnant women $\geq 35$ years old. Pregnant women who are $<20$ years old and $\geq 35$ years old should routinely check their pregnancy to the nearest health facility so that the pregnancy is well monitored and detect early if the mother and baby experience complications of pregnancy.

\section{The effect of maternal education on the incidence of low birth weight}

The results of this study indicate there is an influence between maternal education and the incidence of low birth weight. Mothers who have primary education (<high school) 
are more at risk than mothers who have high education ( $\geq$ Senior high school).

Maternal education is an initial health capital that can be associated with educational associations with available resources related to maternal health. Mothers who are highly educated will tend to have good health input compared to mothers with low education so that it can have an impact on the baby to be born by the mother (Kim and Wickrama, 2016).

A study by Trisnawati et al. (2018) reported that education has an indirect and significant influence on the incidence of low birth weight. High maternal education affects high family income, and low maternal education influences low income.

Other study states that low maternal education will be related to the use of prenatal care services due to lack of awareness to check for pregnancy and low nutritional intake due to low socioeconomic status which also influences purchasing power (Archarya et al., 2018).

Mothers who have further education (high school, university) will reduce the incidence of low birth weight than mothers who have basic knowledge (elementary and junior high school or equivalent). Pregnant women who have basic education (<high school) are expected to be more active in seeking information about pregnancy and diligently checking their pregnancy at the nearest health worker.

\section{The effect of maternal occupation on the incidence of low birth weight}

The results showed that there was a relationship between maternal work and the incidence of low birth weight. Mothers who have work outside the home are more likely to give birth to low birth weight than mothers who work at home. Maternal physical work during pregnancy has a significant relationship with the incidence of low birth weight babies. The proportion of babies born with LBW is gre- ater in mothers who have heavy physical work. One effect arising from heavy physical work is placental hypoxia that leads to low birth weight babies, especially occurs in mothers who also experience nutritional deficiencies in pregnancy. The frequency and duration of rest performed by pregnant women is an important role in determining the birth weight of babies (Sharma et al, 2015).

Work is an activity or activities carried out every day during pregnancy. Work performed by pregnant women plays an important role in the development of the baby conceived. Heavy work can endanger the mother and her womb. The occurrence of premature rupture of membranes often occurs as a result of heavy work, thus making low birth weight babies born to low birth weight babies due to work fatigue (Abdul, 2010).

Mothers who work outside the home have a greater risk of giving birth to low birth weight compared to mothers who work inside the home. It is expected that mothers who work outside the home pay more attention to the frequency and duration of rest during pregnancy because it determines the baby's birth weight.

\section{The effect of family income on the incidence of low birth weight}

The results showed that there was an influence between family income and the incidence of low birth weight. Babies born to low income families will tend to give birth to babies who have low birth weight than babies born to high income families this is because families who have low incomes will be associated with the provision of nutrients less in pregnant women, causing low nutritional status. Family income indirectly influences and is statistically significant on low birth weight babies through gestational age, nutritional status, psychological stress, and environmental sanitation. So that high income will reduce the incidence of low birth weight babies through good nutritional status, ade- 
quate gestational age, and good environmental sanitation and low prenatal stress (Trisnawati et al., 2018).

The results of other studies mention that babies born in families with high incomes have a lower risk of giving birth to low birth weight babies compared to babies born to families that have low family income (Rahayu et al., 2019).

Other supporting research states that family income has an indirect effect on the incidence of low birth weight babies through nutrition in pregnancy. Low family income causes low maternal nutrition in pregnancy (Paramitasari et al., 2018). The low socioeconomic level reduces the purchasing power of good food in terms of quality and quantity (Mergawati and Widjanarko, 2016).

The government is expected to provide assistance to pregnant women who have low incomes such as registration on national health insurance, supplementary feeding of pregnant women and other food assistance so that the nutrition and nutritional status of pregnant women can be fulfilled. It is also expected that pregnant women who have low family income continue to diligently check their pregnancy to the nearest health worker and find information about what foods can meet nutrition during pregnancy.

\section{The effects of maternal knowledge} on the incidence of low birth weight The results of this study indicate that there is a relationship between maternal knowledge and the incidence of low birth weight. Mothers who have good knowledge tend not to give birth to babies who have low birth weight compared to mothers who have bad knowledge, this is related to the level of education of the mother and mother's age. So that high maternal knowledge will reduce the incidence of low birth weight through high maternal education and age who are not at risk for pregnancy. Low public knowledge about high risk babies of low birth weight also becomes an obstacle to reducing the incidence of low birth weight (Situbondo Health Office, 2018).

Low knowledge tends to have bad habit or lifestyle such as eating non-nutritious foods, checking the pregnancy if there are only complaints, choosing and looking for cheap birth attendants such as traditional birth attendants without knowing the consequences of labor that uses unsterile tools. Knowledge is needed in all respects, especially health because knowledge is a process in achieving a health behavior. This shows that the importance of one's knowledge about health issues, especially LBW (Hartiningrum and Fitriyah, 2019).

Good maternal knowledge will reduce the incidence of low birth weight compared to poor maternal knowledge. So that government support is needed to provide knowledge of mothers about low birth weight through classes of pregnant women or existing Integrated Health Posts. It is also expected for pregnant women who have low knowledge to seek information on low birth weight so as to prevent the occurrence of low birth weight.

\section{The effects of cigarette smoke expo- sure on low birth weight events}

The results of this study indicate that there is an influence of cigarette smoke exposure with the incidence of low birth weight. Mothers who are exposed to high cigarette smoke will tend to give birth to babies who have low birth weight compared to mothers who are exposed to low cigarette smoke. Cigarette smoke contains more than 4,00o different chemicals released into the air as particles and gases, including carbon monoxide, ammonia, dimethyl nitrosamine, froma dehide, hydrogen cyanide and acroline (WHO, 2014).

Nicotine is one of the main addictive compounds in cigarette smoke and is a key substance that contributes significantly to various health problems, because nicotine is inhaled and enters the respiratory system will 
be flowed through the blood, very low levels of nicotine will cause transcriptomy modifications that can be detected in respiratory tract epithelium so that it easily crosses the placenta and binds to the nicotinic acetylcholine receptors (nAChRs) that regulate fetal brain development (Lewis et al., 2017).

Higher nicotine levels in amniotic fluid, fetal serum and placenta from maternal serum, nicotine content in cigarettes can damage placental function which causes aberrant placental metabolism, cell damage, apoptasis, abnormal heartbeat in labor and some oxidative damage that can cause severe baby weight to be born (Herman et al., 2016). Exposure to gestational cigarette smoke can affect lung function and gestational age thereby increasing the risk of premature birth (Balte et al., 2016).

Another study stated, mothers who smoked during conception and during pregnancy had an effect on the birth of low birth weight babies. Exposure to cigarette smoke obtained from outside such as cigarette smoke in the environment, cigarette smoke in the workplace and exposure to passive cigarette smoke from family members who smoke, also negatively impact pregnancy which is reported with low birth weight (Mine et al. , 2017). Smoking bans in public places can reduce the risk of premature birth (Díez-Izquierdo et al., 2017).

Mothers who are exposed to high cigarette smoke have a higher risk of giving birth to babies with low birth weight than mothers who are exposed to low cigarette smoke. Pregnant women should make efforts to prevent this by avoiding places where there are many people who smoke, giving understanding to husbands or family members who smoke not to smoke near the mother or in the house, and suggesting the husband to change clothes after smoking so that the mother is not exposed to residue (residue) from cigarette smoke. It is advisable for the govern- ment to make regulations and emphasize these regulations so as not to smoke in public places.

\section{Contextual effect of integrated health posts on the incidence of low birth weight}

The results showed there was no contextual influence at the second level, namely the integrated health posts between the variations in the incidence of $\mathrm{LBW}(\mathrm{ICC}=<0.01 \%)$. ICC value in this study is smaller than the rule of thumb rule of $8-10 \%$. The support of health workers in all integrated health posts strata examined has a good value.

Integrated health post is a variable that has an important role in accessing services provided by the community to health providers in the vicinity. Integrated health posts consist of several levels, namely pratama, madya, purnama and mandiri (Ministry of Health, 2011).

According to Suryandari (2016), the results of the study show that there are several factors that influence the Integrated health posts strata of age, old cadres and knowledge. There is no influence between work and integrated health posts strata. In conclusion, the influence of variables for integrated health posts strata is age, old cadres, and knowledge. In addition, there are also several other factors to assess integrated health posts strata such as frequency of weighing, average cadre of tasks, average D / $\mathrm{S}$ coverage, cumulative coverage of $\mathrm{MCH}$, cumulative coverage of family planning, cumulative coverage of immunizations, additional programs, coverage of healthy funds.

So it can be concluded that not only the support of health workers can influence the integrated health posts strata but many other factors are interrelated so that other factors that support also need to be considered by the government and related health centers so that the quality of integrated health posts is better and in accordance with the scope and 
Kuswandari et al./ Do the integrated health posts have contextual effect on LBW

target from each stratum.

\section{AUTHOR CONTRIBUTION}

Eti Kuswandari was the main author who plays a role in conducting stduy, collecting the data, wrote the articles, and processing data analysis. Harsono Salimo played a role in suggesting materials for discussion. Yulia Lanti Retno Dewi played a role in formulating of the framework of research thinking and data analysis.

\section{CONFLICT OF INTEREST}

There is no conflict of interest in this study.

\section{FUNDING AND SPONSORSHIP}

This study is self-funded.

\section{ACKNOWLEDGEMENT}

Acknowledgments were conveyed by researchers to the Head of the Puskesmas Asembagus Puskesmas Working Area for allowing this research to be carried out. Thanks to respondents who have been willing and cooperative to be the subject of research.

\section{REFERENCE}

Abdul A (2010). Pelayanan Kesehatan Maternal \& Neonatus (Maternal \& Neonate Health Services). Jakarta: Bina Pustaka Archarya D, Singh J, Kadel R, Yoo SJ, Park J $\mathrm{H}$, Lee K (2018). Maternal Factor and Utilization of the Antenatal Care Services during Pregnancy Associated with Low Birth Weight in Rural Nepal : Analyses of the Antenatal Care and Birth Weight Records of thr. Int J Environ Res Public Health. 15(11): 1-14. http://doi.org/10.3390/ijerph15112450.

Agorinya IA, Kanmiki EW, Nonterah EA, Tediosi F, Akazili J, Welaga P, Azongo D, Oduro AR (2018). Socio demographic determinants of low birth weight: Evidence from the Kassena-Nankana districts of the Upper East Region of
Ghana. PloS one. 13(11): 1-10. http://doi.org/10.1371/journal.poe.0206207.

Baltea P, Karmaus W, Roberts G, Kurukulaaratchy R, Mitchell F, Arshad H (2016). Relationship between birth weight, maternal smoking during pregnancy and childhood and adolescent lung function: A path analysis. Respir Med, 121: 13-20. http://doi.org/10.1016/j.rmed.2016.10.010.

Díez-izquierdo A, Balaguer A, Moyano CL, Sánchez J C M,Galán I, FernándezE , Jose M (2017). Correlation between tobacco control policies and preterm births and low birth weight in Europe. Envres. 1-6. http://doi.org/10.1016/j.envres.2017.10.033.

Dinas Kesehatan Provinsi Jawa Timur (2018). Profil Kesehatan Jawa Timur (Health Profile of East Java). Surabaya: Dinas Kesehatan Provinsi Jatim. http://dinkes.situbondokab.go.id/dinkes/

Fukuda S, Tanaka Y, Harada K ,Saruwatari A, Kitaoka K, Odani K, Aoi W, Wada S, Nishi, Oguni T, Asano H, Hagiwara N, Higashi A (2017). High maternal age and low pre-pregnancy body mass index correlate with lower birth weight of male infants. Tohoku J Exp Med, 241 (2): 117-123. http://doi.org/10.1620/tjem.241.117

Herman GH, Miremberg H, Nini N, Feit H, Schreiber L, Bar J, Kovo M (2016). The effects of maternal smoking on pragnancy outcome and placental histopathology lesions. Reprod Toxicol. http://doi.org/10.1016/j.reprotox.2016.05.022

Hartiningrum I, Fitriyah N (2019). Bayi berat lahir rendah (BBLR) di Provinsi Jawa Timur tahun 2012-2016 (Low Birth weight babies in East Java Province 2012-2016). JBK, 7(2): 97. http://doi.org/10.20473/jbk.v7i2.2018.97104

Hidayat A, Jahari A (2011). Perilaku peman- 
Kuswandari et al./ Do the integrated health posts have contextual effect on LBW

faatan posyandu hubungannya dengan status gizi dan morbiditas balita (Utilization behavior of posyandu relationship with nutritional status and morbidity of children under five years old). Pusat Teknologi Terapan Kesehatan dan Epidemiologi. 1-10

Joshi HS, Srivastava PC, Agnihotri A K, Joshi MC, Shalini CV, Mahajan (2011). Original research paper Risk Factors for Low Birth Weight (LBW) Babies and its Medico Legal Significance Abstract: Introduction: Material and Methods: Corresponding Author: Statistical.

Kim J, Wickrama KAS (2016). Maternal social status, early health capital, and young adults' economic attainment: Early life course investigation. Social Science Research. Elsevier Ltd. doi: 10.1016/j.ssresearch.2016.06.022.

Lewis JB, Hirschi KM,Arroyo, JA, Bikma, BT, Kooyman DL, Reynolds PR (2017). Plausible roles for RAGE in conditions exacerbated by direct and indirect (Second hand) Smoke Exposure. Int $\mathrm{J} \mathrm{Mol}$ Sci, 18(3): 2-22. http://doi.org/10.339o/ijms180-30652.

Maryunani A (2009). Asuhan Kegawat-daruratan dan Penyulit Pada Neonatus (Emergency care and complications in neonates). Jakarta: TIM.

Margawati AR, Widjanarko B (2016). Pengaruh status gizi \& asupan gizi ibu terhadap berat bayi lahir rendah pada kehamilan usia remaja. Jurnal Gizi Indonesia, 5(1): 14-19. doi: https://doi.org/10.14710/jgi.5.1.14-19.

Mine T, Tanaka T, Nakasone T, Itokazu T, Yamagata Z, Nishiwaki Y (2017). Maternal smoking during pregnancy and rapid weight gain from birth to early infancy. J Epidemiol. Elsevier Ltd, 27(3): 112-116. http://doi.org/10.1016/j.je.2016.10.005.

Ministry of Health (2011). Pedoman umum pengelola posyandu (General guidelines for integrated health post managers). Jakarta: Kementerian Kesehatan RI.

Ngwira A, Stanley CC (2015). Determinants of low birth weight in Malawi: Bayesian Geo Additive Modelling. PLoS ONE, 10(6): 1-14. http://doi.org/10.1371/journal.pone.01-30057

Pantiwati I (2010). Bayi dengan BBLR (Berat badan lahir rendah) (Babies with LBW low birth weight). Yogyakarta: Nuha Medika

Paramitasari NM, Salimo H, Murti B (2018) The effect of biological, social, economic, and nutritional factors on low birth weight: A new path analysis evidence from Madiun Hospital, East Java, Indonesia. J Matern Child Health, 3: 166-175. https://doi.org/10.26911/thejmch.2018.03.03.01.

Rahayu ZB, Budhiastuti RU, Rahardjo SS (2019). Analisis multilevel determinan biopsikososial puskesmas dan modal sosial terhadap kejadin bayi berat lahir rendah di Kabupaten Lombok Timur NTB (Multilevel analysis of biopsychosocial determinants of health centers and social capital against low birth weight babies in East Lombok Regency, NTB). J Matern Child Health, 4(3): 136-145 https://doi.org/10.26911/ thejmch.2019.09.20

Proverawati A (2010). Berat badan lahir rendah (Low birth weight). Yogyakarta: Nuha Medika

Sharma SR, Giri S, Timalsin U, Bhandari S S, Basyal B, Wagle K, Sharestha L (2015). Low birth weight at term and its determinants in a tertiary hospital of nepal A case-control study. PLoS ONE, 10(4): 1-10. http://doi.org/10.1371/journal.pone.01-23962.

Situbondo Health Office (2018). Profil Kesehatan Kabupaten Situbondo (Situbondo 
Kuswandari et al./ Do the integrated health posts have contextual effect on LBW

Regency Health Profile). Situbondo: Dinas Kesehatan Kab.Situbondo. http://dinkes.situbondokab.go.id/dinkes/

Situbondo Health Office (2019). Profil Kesehatan Kabupaten Situbondo (Situbondo Regency Health Profile). Situbondo: Dinas Kesehatan Kab. Situbondo. http://dinkes.situbondokab.go.id/dinkes/

Suryandari AE, Happinasari O (2016). Factors affecting the integrated health posts strata. The 4th Proseding University Research Qolloquim: 193-198.

Trisnawati I, Salimo H, Murti B (2018). Low birthweight and its biopsychosocial and economic determinants: A new evidence using a path analysis model from Jambi, South Sumatera. J Matern Child Health, 3(1): 1-10. https://doi.org/10./thejmch.2019.09.20

WHO (2014). Global nutrition target 2025 low birth weight policy brief. https://www.who.int/-nutrition/publications/globaltargets2025_policybrief_lbw/en/

WHO (2017). Feto-maternal nutrition and low birth weight. Geneva: WHO. Retrieved from : http://www.who.int/-nutrition/topics/feto_maternal/en/(7 July 2017)

Yowono AW (2015). Pengaruh tingkat sosial ekonomi, karakteristk ibu hamil dan perilaku ibu hamil terhadap kejadian BBLR (berat badan lahir rendah) di wilayah kerja Puskesmas Lamongan tahun 2015 (Effect of socio-economic level, characteristics of pregnant women and pregnant women behavior on the occurrence of LBW) in Lamongan Health Center in 2015). Swara Bhumi, 4(4): 53-61 